\title{
Carceral moderation \\ and the Janus face of international pressure: \\ A long view of Greece's engagement with the European Convention of Human Rights
}

\author{
Sappho Xenakis and Leonidas K. Cheliotis
}

In recent years there has been considerable scholarly debate about the factors determining the efficacy of international human rights rules and norms. Little effort has been made, however, to bring this body of research to bear on the study of human rights violations relating to conventional imprisonment and immigration detention. This is surprising, both because of the high volume of violations known to have been occurring within prisons and immigration detention centres around the world, with a parallel rise in legal and civic forms of mobilisation seeking to address the problem, and because broad recognition has been paid to the need for considering international factors and actors when accounting for national- and local-level developments in the field of incarceration.

With a view to helping fill this gap in the literature, this article examines the pressure exerted by the European human rights regime on Greece, assessing the efficacy of the pressure as such (both in terms of the acceptance and implementation of pertinent rules and norms) and identifying the array and relative significance of the forces that have given shape to it over time. ${ }^{1}$ In particular, our analysis takes a long historical perspective to gauge and account for the degree to which conditions of incarceration (including, for more recent years, immigration detention) in Greece have been influenced by the European Convention of Human Rights (ECHR) through derivative judicial and monitoring mechanisms: the European Court of Human Rights (ECtHR) and the Committee for the Prevention of Torture, Inhuman or Degrading Treatment or Punishment (CPT), respectively.

Greece readily lends itself as a case study through which to advance understanding of the effectiveness of pressure from the European human rights regime towards national compliance with ECHR provisions on incarceration. On one hand, as a relatively weak state within Europe, Greece might reasonably be expected to have been more likely to succumb to pressure from powerful continental actors to align its policies and practices with the Convention. On the other hand, Greece has a long and turbulent history of engagement with the ECHR, including an exceedingly poor record of compliance with a number of its provisions. Crucially for present purposes, Greece's non-compliance has concerned conditions of incarceration with increasing frequency over the last twenty years or so, as attested by a long series of damning reports by the CPT during this timeframe and the concurrent upsurge in the number of convictions

\footnotetext{
${ }^{1}$ We use the standard definition of the term 'regime' to denote sets of 'implicit or explicit principles, norms, rules, and decision-making procedures around which actors' expectations converge in a given area' (Krasner 1982: 185).
} 
of the country by the ECtHR for violation of Article 3 of the Convention, which prohibits inhuman or degrading treatment or punishment.

We begin by reviewing extant research, primarily but not solely from the fields of Law and International Relations, on the nature and effectiveness of pressure through which international human rights regimes seek to promote national compliance with their rules and norms. In so doing, we outline the main arguments that can be distilled from this literature to explain non-compliance, and proceed to test their validity in the context of Greece with particular reference to conditions of incarceration over two historical periods: first, from the mid-twentieth century, when Greece joined the CoE and signed the ECHR, until the fall of the country's seven-year military dictatorship in 1974; and second, the ensuing decades, including the time elapsed since a coalition government led by the left-wing Syriza party assumed power in 2015, shortly after the collapse of a centrist two-party system that had been in place since the restoration of democracy. We conclude by summarising our findings on the causes behind Greece's longstanding non-compliance with the ECHR in the field of incarceration, also highlighting the implications of these findings for the study of international human rights regimes and the effectiveness of their interventions inside nation-states. The Greek case suggests that, in conjunction with select institutional capacity constraints, a range of domestic and international pressures, material as well as social, may combine to offset international pressure for national compliance with international human rights regimes. This not only adds impetus to warnings against mono-causal approaches that are bound to overlook the possibility of multiple forces operating simultaneously and cumulatively to produce non-compliance; it also calls attention to the diversity and potentially competing nature of influences stemming from the international sphere.

\section{The efficacy of international pressure on national human rights performance: A brief review of the literature}

'Realist' approaches to international relations have typically underscored the fundamental inequality of the international system, encapsulated in the dictum 'the strong do what they can, the weak do what they must', recorded by Thucydides. From such perspectives, international regimes emerge and survive according to the whim of stronger states, and weaker states can be expected to comply with such regimes, whether promptly with enthusiasm or reluctantly with delay. Thus, in his study of the historical trajectories of various international prohibition regimes (e.g., tackling slavery, piracy, and alcohol), Nadelmann (1990) posits that their fate was ultimately determined by great power support (or lack thereof). As regards specifically the international human rights regime, Krasner (1999) similarly argues that pressures for compliance stemming from the international arena are only likely to find success in instances in which compliance is also in the interest of a global hegemon. As a rule, moreover, states are known to be wary of entering into international commitments such as human rights conventions and related obligations that risk exposing them to unwanted scrutiny and criticism (Smith 2015).

The expansion of the international human rights regime over successive decades - both in terms of membership and scope of activity - appears to pose a conundrum for approaches that privilege the role of stronger actors in 
explaining the status of international rules and norms. Since the early 2000s alone, through the development of the International Criminal Court, a new model of criminal accountability has emerged to hold individuals responsible for human rights violations, whilst a new international human rights norm has also been heralded: the responsibility of the international community to intervene in cases where citizens' own states are unwilling or unable to protect them from gross human rights violations (known as 'Responsibility to Protect', or 'R2P') (Risse and Ropp 2013). Within Europe, which has been regarded as something of a hot-spot of international human rights promotion and compliance by global comparison, there are today more human rights treaties, more human rights organisations, more human rights commissioners and more human rights prizes, than ever before (Knaus 2015a). But how is it that the international human rights regime has seen successive growth without the full support of key international powers, such as the US, Russia and China, above and beyond the broader opposition that has arisen internationally to the human rights agenda over the last decade or so (Smith 2015)? How is it, equally, that within Europe the human rights regime has appeared to reach unprecedented heights at the same time that strong states such as Britain and France have challenged its reach, and that human rights rules and norms are increasingly met with either indifference or hostility (Knaus 2015b)? And how is it that in recent years, in both global and regional arenas, human rights rules and norms have continued to develop at the same time that countries with poor human rights records have been made chairs of key committees in international bodies (UN Watch, September 20, 2015; Knaus 2015)? ${ }^{2}$

Variation in compliance with the international human rights regime also needs to be accounted for, particularly since the regime has generally lacked the type of hard enforcement mechanisms that accompany other types of international legal regimes (Cardenas 2007). Comparative studies have shown that substantial disparity exists between the compliance records of states towards international human rights rules and norms (see, e.g., Anagnostou and Mungiu-Pippidi 2014). International human rights rules and norms, meanwhile, are not entirely without enforcement mechanisms; economic sanctions and monetary fines, for example, are two moderately hard enforcement tools that can be used, respectively, by and within the Council of Europe and its member states to punish non-compliance with international and regional human rights standards. Such mechanisms are only used comparatively rarely to punish noncompliance (Smith 2015; Hillebrecht 2014b), however, and their sparse usage makes the breadth of the regime all that more perplexing.

So-called 'constructivist' approaches to power have nonetheless long argued that influence in the international arena does not necessarily flow from material power alone or, indeed, at all (Friman 2015). Constructivists rather

\footnotetext{
2 In 2011, for example, an Azerbaijani representative who consistently praised Azerbaijan's President Aliyev as well as prison conditions in that country, despite NGO criticisms of its human rights abuses and imprisonment of political opponents in particular, was elected president of the Council of Europe's Committee for the Prevention of Torture (Knaus 2015). Similarly, in 2015, Saudi Arabia's representative to the UNHCR was made chair of the five-member Consultative Group that appoints independent human rights experts as 'Special Procedures of the Human Rights Council' (see further UN Watch, September 20, 2015), despite widespread criticism of the Kingdom's human rights record, including a rising number of judicial executions.
} 
contend that ideational attractiveness - 'soft', co-optive dimensions of power, in other words - play a far more important role in state behaviour than is admitted by materialist accounts (Nye 1990). According to constructivists, international regimes are established by inter-state institutions and non-governmental organisations alike, achieving compliance through socialisation, with soft, social mechanisms of control spanning persuasion, assistance, monitoring, and naming and shaming. Non-compliant states subjected to naming and shaming have been more susceptible to experiencing psychological reactions of shame to the extent that they have internalised the rules and values of the regime, on one hand, and have regarded the allegations of violations as accurate and legitimate, on the other. As Friman (2015) details, however, shame is but one of several possible psychological reactions to public exposure, and may not necessarily lead to compliance in any case. It is clear, moreover, that for some states, actions such as ratifying human rights treaties or attaining membership of human rights bodies, have been entirely cynical, strategic means to an end; whether that be membership of an institution coveted for its status and influence in world politics (Lebovic and Voeten 2006), or deflecting attention and criticism from their own abusive practices (Hafner-Burton 2008; Hafner-Burton and Tsutsui 2005).

One of the most influential constructivist accounts of varying compliance with the international human rights regime, the five-stage 'spiral model' of Risse and Sikkink (1999), presents a thesis of incremental regime development in which human norms and practices become embedded in state discourses, institutions and practices in contexts where normative as well as material international and domestic pressures successfully interweave. In Risse and Sikkink's model, international institutions and transnational networks are thus flagged as key drivers of state compliance with human rights rules and norms. The significance of such pressures, it is suggested, is evidenced from the growth of the international human rights regime from the mid-1980s to the mid-1990s, a period which saw the coincidental expansion of the regime across states home to very different institutional and political arrangements. The importance of international factors in driving the development of the human rights regime has been further supported by research suggesting that the very success of the regime over that timeframe generated a 'bandwagonning' effect, which sustained and increased its attractiveness (Lebovic and Voeten 2009). ${ }^{3}$

The credit given to international factors in accounts of national compliance with the international human rights regime has itself been subject to growing critique, however (Hillebrecht 2014b). Longitudinal international comparative research has demonstrated the practice of naming and shaming non-compliant states to be a largely ineffective strategy to stimulate compliance (Hafner-Burton 2008), despite the fact that it may in some circumstances also indirectly generate financial costs to a non-compliant state (Lebovic and Voeten 2009). Even criticism levied by non-governmental bodies, which has been found to have a closer association with improved human rights outcomes than that issued by intergovernmental organisations, has been found to be of uneven effectiveness (Franklin 2008), contributing to improved human rights outcomes

\footnotetext{
${ }^{3}$ On the ideational appeal of the policies of powerful international actors, see further Linos, 2013.
} 
in autocracies but with no effect or even a worsening of outcomes in democracies and hybrid regimes (Hendrix and Wong 2012).

A different influential line of argument privileges the domestic arena, focusing on the notion of national institutional capacity as the primary determinant of compliance with international human rights rules and norms. Studies have found national compliance to be positively correlated with stronger and more efficient national bureaucracies, although no association has been found between levels of compliance and levels of national economic development (see, e.g., Cole 2016, 2015; Anagnostou and Mungiu-Pippidi 2014; Hillebrecht 2014b). At the same time, the thesis that non-compliance is often inadvertent and conditioned by a state's ability to implement pertinent rules and norms (Cole 2015) has chimed with the rise of 'co-operative' approaches to compliance within Europe, which have seen political and policy elites advocating technical assistance and supportive language -rather than naming and shamingas the most appropriate means of dealing with non-compliance (Smith 2015). Interpreted in this way, however, the privileging of domestic capacity as an explanans of differential compliance has given rise to concerns that states that do not comply are thereby effectively exculpated, when - as human rights NGOs have pointed out - violations are often the outcome of deliberate state policy, rather than of a state's failure to act or lack of capacity to protect (ibid.).

Others have pointed to a wider array of factors that determine domestic capacity to comply with international rules and norms, from the openness of political decision-making to external influence (Hillebrecht 2014a; see also David-Barrett and Okamura 2016), to the health of national finances, to the broader socio-political culture in the country and levels of awareness and education amongst those who would be rule and norm promoters (from NGO activists to lawyers and prosecutors; see further Kaboglu and Koutnatzis 2008). Indeed, it is striking that even in Europe -a region where human rights have been described as having become 'embedded in the politico-cultural ideal' (van Zyl Smit and Snacken 2009), and which enjoys relatively strong institutional capacities across its membership- member-states have tended to comply only partially with adverse rulings against them from the ECtHR, typically treating their human rights compliance obligations 'like choices on a menu' (Hillebrecht 2014b).

In sum, three basic arguments can be distilled from the above review to explain the ineffectiveness of international pressures in promoting national compliance with human rights rules and norms. First, states may have signed up to the international regime but have performed insufficiently due to various 'capacity' limitations in the domestic arena. Secondly, resistance by noncompliant states may be explained instead by reference to the fact that the social and material costs imposed by international actors have been inadequate to overcome the inertia or incentives behind non-compliance. Thirdly, the resistance of non-compliant states to international pressure may be accounted for by the existence of a powerful international counter-regime that serves to undermine the potency of the international human rights regime itself. In what follows, we explore these arguments in the context of Greece, with particular reference to Greece's longstanding failure to comply with the ECHR in the fields of imprisonment and immigrant detention. 


\section{Greek non-compliance with the European human rights regime: An historical perspective}

Greece's persistent recalcitrance in complying with the ECHR appears paradoxical given the country's long and continuing history of submission to repeated and sustained foreign intervention in its political and legal arrangements. Since achieving independence from 400 years of Ottoman rule in the early 1800s, illustrations of the extensiveness of the country's experience of Great Power involvement have ranged from political parties being named after foreign states, to its secret service being established by a foreign power (see further Gallant 2016). Relatedly, Greece's economic marginality has been equally deeply engrained; notwithstanding notable national economic growth in the latter half of the $20^{\text {th }}$ century, it is indicative that the country has defaulted on its external loans seven times since attaining statehood. Indeed, the most recent default also resulted in an extraordinary transfer of control of Greece's governance to foreign institutions to whom Greece was indebted (the European Commission, the European Central Bank, and the IMF; see further Dertilis 2016). Within the context of the European Union, meanwhile, although membership has grown over recent decades to include states with weaker economies, Greece has maintained rates of poverty and inequality that have stood stubbornly amongst the highest in the region. For a state thus very much of the global semi-periphery (see further Cheliotis and Xenakis 2010), the incentives and pressures relating to membership of an elite community such as the CoE, and the adoption of associated rules and norms, have been particularly acute. Indeed, relatively high levels of support for the pursuit of European integration amongst the Greek public and political and intellectual elites have been driven by the perceived imperative of redressing the country's undue marginality in the international arena (see further Herzfeld 1992).

From early on, the relationship between Greece and the European human rights regime was not one that would fit the expectations of Risse and Sikkink's constructivist 'spiral' model of a slow process of human rights criticisms first meeting official resistance and then eventual concessions. Nor, during the period in which Greece joined the Council of Europe (1949), signed the European Convention of Human Rights (ECHR) (1950), and incorporated the Convention into Greek law (1953), was the European human rights regime so developed and powerful that it could be credited with having induced Greek adherence by dint of its success. Rather, as we elaborate below, Greece's actions at this time were entirely driven by strategic objectives (both domestic and international) and its relationship to the human rights regime was wholly superficial. The year that Greece joined the Council of Europe saw the conclusion of a four-year civil war in the country, which itself had followed a five-year right-wing military dictatorship (1936-41). Decades of illiberal rule were to continue against the broader backdrop of the Cold War: emergency anti-communist legislation that originated during the Greek Civil War was only formally abolished in 1962, and its harsh provisions were all too quickly revived by the country's military junta of 196774 (see further Cheliotis and Xenakis 2016).

One interpretation of Greece's attitude towards the ECHR at this juncture is that 'the Greek authorities neither examined nor understood the obvious inconsistency of a considerable part of domestic legislation with the ECHR as an obstacle to its incorporation. [...] Accession to the CoE and the ECHR was aimed 
at concealing rule of law deficits and securing their participation in the Western alliance' (Kaboglu and Koutnatzis 2008: 452, 454). According to this logic, the substance of the ECHR was irrelevant to the concerns of Greece's political leadership, whilst years of thorough political purging ensured that the country's judiciary, being guided only by subservience to the prerogatives of government, posed no challenge to substantive political disinterest in the ECHR. The proactivity of Greece in upholding international compliance with the ECHR during the same period challenges this interpretation, however. In 1956, within three short years of incorporating the ECHR into domestic legislation, the Greek government launched a challenge to the first-ever attempt by a member of the CoE to derogate from the ECHR.

Greece's 1956 petition of the ECtHR concerned Britain's use of emergency powers in Cyprus, claiming that the level of threat to life on the island was insufficient to justify Britain's derogation under Article 15 of the treaty, and that the British were violating the human rights of Greek Cypriots by deporting and imprisoning suspects illegally, flogging juveniles, imposing collective punishments, and torturing individuals. When the CoE removed the accusations of torture from the petition, the Greek government took the step of raising them at the UN as well as returning a new petition about British torture practices in Cyprus to the ECtHR the following year (French 2015). Greece dropped its complaints two years later as part of the Zurich peace agreement for the island. Whilst the British had impeded the work of the CoE sub-commission to which they had reluctantly agreed and the investigators' report was never published, the Greek petition arguably succeeded in shaming Britain into ceasing some of its abusive practices on the island (French 2011). Thus, prior to Greece's own invocation of Article 15 of the ECHR in 1967, the country had clearly demonstrated familiarity and engagement with the Convention, as well as with the limitations of the ECtHR. Indeed, it is Greece's very experience as a notable prior petitioner of the ECtHR that helps to explain why the country's government made the effort of applying for derogation from the ECHR shortly after the military coup of 1967.

Despite Greece's apparently keen engagement with the ECHR early on, soft and hard pressure subsequently exerted by the country's international human rights critics was unable to bring a halt to human rights abuses under the junta. In September 1967, the Netherlands, Sweden and Denmark lodged an application at the ECtHR concerning eight violations of the ECHR by Greece (ranging from mass internment and trials before extraordinary court martial to media censorship), to which a further violation, of Article 3, was subsequently added following the publication of reports by Amnesty International about torture being carried out by the Greek authorities (Evans and Morgan 1998: 80). Indeed, NGOs such as Amnesty International played an important role in mobilising European publics against the junta's crimes, and thereby also indirectly influenced the stance European governments took towards Greece. In late 1969, the European Commission of Human Rights rejected Greece's application to derogate from the ECHR and found multiple violations, including torture and ill-treatment of political detainees as well as unacceptable conditions of detention (Kaboglu and Koutnatzis 2008). This step came after a decision by the European Parliament in 1967 to freeze the EEC association agreement with Greece, including negotiations over issues such as agricultural policy 
harmonisation, \$56 million of EEC development loans and further development financing (Xydis 1974).

Rather than comply in the face of these external pressures, Greece invoked the abuses of the British in Cyprus (Papandreou 1998), denied the truth of the allegations, rebuked the CoE for unduly intervening in the sovereign affairs of the Greek state, and anticipated the country's expulsion from the CoE by withdrawing from the organisation itself in December 1969. Greece's defiance towards human rights criticism from its European counterparts was fuelled by confidence in its geostrategic importance to the US and to West European states as a member of the anti-communist NATO alliance, especially in the aftermath of the crushing of the Prague Spring by the Soviets in 1968. Continuing arms sales from its allies, in particular, served to embolden the Greeks and diminish their concern about critical discourses from their international partners (see, e.g., Nafpliotis 2014; Pedaliu 2011). In 1970, against the background of ongoing international criticism of human rights abuses, it was the looming prospect of a new round of US Senate hearings on military aid in Greece that encouraged the junta to take steps towards the temporary liberalisation of the regime including the release of detainees (Woodhouse 1985).

Given the superficial nature of Greece's approach to the ECHR, it was unsurprising that no domestic legislative changes ensued after the country's withdrawal from the $\mathrm{CoE}$, and the 1953 statute formally remained in force. Equally testament to the embedded character of such attitudes, however, is that whilst after the collapse of the junta the incoming Greek government under the premiership of Costas Karamanlis sought to demonstrate its commitment to democracy and liberal democratic values (generally conceived) by swiftly reapproving the ECHR and readily accepting the Council of Europe's early invitation for the country to rejoin the association (prior even to the holding of national elections), the potential ramifications for Greek law did not attract interest and the ECHR was largely absent from parliamentary debates about the wording of a new constitution (Kaboglu and Koutnatzis 2008; Karamouzi 2014).

\section{Greek non-compliance in the contemporary period}

In 1975, following the restoration of democracy, Greece adopted a new constitution that included an extensive bill of rights. The country went on to recognise the compulsory jurisdiction of the ECtHR in 1979 and the right of individuals to petition the ECtHR in 1985, and ratified the European Convention for the Prevention of Torture and Inhuman or Degrading Treatment or Punishment (which established the inspections monitoring regime of the eponymous Committee, known as the CPT) in 1991. Until the 1990s, however, Greek courts usually did not cite case law emanating from the ECtHR and reflecting their continuing subservience to domestic political leadership - tended to reject claims of ECHR violations without consideration of their merit. On occasions where such claims were given substantive consideration, Greek courts typically relied on the provisions set out by the national constitution, only rarely and fleetingly acknowledging the relevance of the ECHR. Since the late 1990s, Greek courts have demonstrated greater awareness of, and deference to, the provisions of the Convention. The number of applications lodged against Greece with the ECtHR has nevertheless risen steadily since the right to individual petition was recognised. The number of violations found by the ECtHR to have 
been committed by Greece has also increased steadily, with a particularly dramatic rise evident during and since the 2000s. Indeed, the country has one of the highest violation rates of states signatory to the Convention (see, e.g., Anagnostou and Mungiu-Pippidi 2014).

Between 2001 and 2015, Greece received at least 55 convictions under Article 3 of the Convention, the overwhelming majority of which were received between 2010 and 2015 (Chatzitheodorou 2016). Most of these cases have concerned the rights of either foreigners facing deportation or pre-trial detainees, and the majority of violations have related to the length of proceedings, the right to a fair trial, and the provision of an effective remedy. Recent years have seen a wider thematic diffusion of violations, including those relating to the right to life, freedoms of expression, and the prohibition of inhuman or degrading treatment or punishment. With regard to the latter, ECtHR decisions against Greece have typically concerned minimal healthcare provision and poor material conditions (e.g., insufficient floor space, lack of ventilation and hot water, unsuitable room temperature and poor hygiene) in conventional prisons, in detention spaces inside police stations, and increasingly over recent years, in sites of administrative detention of irregular migrants (see further Cheliotis 2012, 2013; also Galanou 2011; Chatzitheodorou 2016).

Findings against Greece by the ECtHR -and also, in exceptional instances, by domestic courts- have involved the awarding of considerable monetary damages to victims (see further Cheliotis 2012, 2013). According to ministerial sources, between 2011 and 2015 alone, the 16 convictions Greece received by the ECtHR involved fines totaling €1,646,000 ( $\mathrm{Ta}$ Nea, 18 February 2016). Yet Greece has one of the poorest records of ECHR signatory states in implementing the judgments of the Court (Anagnostou and Mungiu-Pippidi 2014). Indeed, the ECtHR ruled in 2011 that detention practices in Greece violated Article 3 of the ECHR and therefore that other EU member states should cease transferring migrants to the country under the Dublin-II agreement (Cheliotis 2013). Greece's persistent failure to improve conditions of imprisonment and immigration detention has also been subject to a long series of damning reports by the CPT, culminating in an 'exceptional public statement' in March 2011. This was only the sixth public statement to have been issued by the Committee throughout its entire 22-year existence at that juncture. Such statements are the sole form of sanction the CPT may apply when national authorities consistently fail to make the changes requested (Cheliotis 2012), although CPT reports have also themselves become an increasingly important source of evidence for ECtHR judgments (van Zyl Smit and Snacken 2009). Since then, two further CPT reports have been published on Greece which have also been highly critical of persisting and worsening problems bedevilling conditions of imprisonment and detention in the country (in 2014 and 2016), alongside a host of damning reports by national and international NGOs and media organisations.

Greek governments have long responded to critical CPT reports with a combination of denial and defiance. Forms of denial in official responses to CPT reports have ranged from simply 'ignoring findings of risks of ill-treatment' (Evans and Morgan, 1998: 207) to dismissing criticisms as 'unfounded and offending [sic]' (Government of Greece, 2010: 63) - both in terms of fact (that illtreatment occurred at all) and degree (that they were anything more than 'isolated incidents'). Greek officials have even challenged the validity of CPT 
criticisms by claiming that prison conditions and the treatment of prisoners are more favourable in Greece than in most of its European counterparts (see further Cheliotis 2012). To the extent that criticisms have been accepted, responses to the CPT have commonly drawn attention to capacity limitations (from financial restrictions to staffing shortages) facing the Greek state in ameliorating conditions within prisons and immigration detention centres, whilst insisting that the country is working towards solutions to the problems at issue, whether through ongoing investigations (e.g., into allegations of abuse by staff) or planned legislative and practical interventions. Yet blame has often been deflected onto prisoners and detainees themselves and, with regard to the treatment of irregular migrants and conditions within administrative detention centres specifically, the Greek government has also complained that the CPT has failed to acknowledge the particular pressures on Greece as a major entry-point for irregular migration into the EU (Government of Greece 2009). ${ }^{4}$

Notwithstanding these entrenched discourses of denial, Greece has responded at least to problems of overcrowding in conventional prisons -often prompted to do so by prisoner riots (see further Cheliotis 2010, 2011)- through partial initiatives, including the construction of extra accommodation at existing sites and a prison-building programme. Between 1994 and 2009, the total certified accommodation in the country's prisons rose by over $130 \%$. Although during this period the ratio of prisoners to certified accommodation was thereby reduced from 1.76 to 1.28 , severe overcrowding continued, especially in certain establishments (such as the male prison of Korydallos; ibid.). This was due to a combination of longer custodial sentences being handed down and limited use of early releases for prisoners, despite crime rates having risen at a significantly lower rate over the same timeframe than would plausibly justify the pace of expansion in the prison population (ibid.).

A significantly bolder step was taken in April 2015, when the Greek parliament passed a prison reform bill that sought to relieve prison overcrowding through a range of measures, such as limiting the range of imprisonable offences for young people, setting limits to the prolonged detention of foreigners facing deportation after expiry of the custody term set by courts, and, most controversially, relaxing the eligibility criteria for parole, especially but not solely for disabled prisoners. One-day snapshot measurements published by the Greek Ministry of Justice itself indicate that the total prisoner population underwent a notable 18.7\% reduction between 1 April 2015 and 1 October 2016, dropping from 11,602 to 9,422 . This constituted the largest contraction in the prisoner population in over three decades, during which ever-expanding prisoner numbers had rather been the norm (Cheliotis 2011). It is difficult to ascertain the precise degree of responsibility that can be attributed to the European human rights regime for such steps (see further Anagnostou 2013: 213). The regime nevertheless received considerable credit for generating the recent reforms when the Greek Minister of Justice spoke out to defend them against domestic critics, explicitly referring to 191 outstanding cases against

\footnotetext{
${ }^{4}$ Beyond the CPT, Greece has more generally complained in the past that her European counterparts ought to do more to mitigate the disproportionate burden placed on Greece as the principal entry-point to the EU of irregular migrants, and has also suggested that Turkey has facilitated the heavy influx of irregular migrants to the country.
} 
Greece at the ECtHR over prison conditions and to continuous and expensive convictions of the country by the Court (Christou-Prentziou 2015).

The overall picture that emerges from inside Greek prisons has remained dire (see, e.g., Efimerida ton Syntakton, 18 September 2016; To Pontiki, 9 October 2016), however, whilst conditions within immigration detention centres and other sites where irregular migrants are forcefully kept (e.g., police stations and reception centres) have continued to attract widespread infamy internationally (see, e.g., Human Rights Watch 2016). ${ }^{5}$

\section{Accounting for Greek non-compliance}

\section{Domestic capacity arguments}

As already mentioned, Greek non-compliance with human rights norms has been explained in official discourse and socio-legal scholarship alike by reference to 'capacity' limitations, with accounts variously stressing resource and institutional constraints.

In its official response to the CPT in 2012, for example, Greece invoked its ongoing financial crisis, stating: '[There are] well-known fiscal problems that our country [has been] facing [over] the past 1.5 years. We will not get into details, because we think it is self-evident that the lack of financial resources implies insurmountable obstacles to the implementation of an effective correctional policy, as with any other public policy' (Government of Greece 2012). Financial difficulties due to economic downturn have also been evoked by Greek state authorities in an effort to explain away responsibility for the conditions in immigration detention centres across the country (Cheliotis 2013). In fact, however, financial obstacles to Greek compliance with the ECHR have stemmed more from the way in which funding is administered than the availability of financial resources per se. Gross underfunding of the country's prison system, for instance, has a history that far exceeds the reach of the financial crisis which broke at the end of the 2000s, although knowledge of precise budget allocations has been scant (see, e.g., Dimopoulos 1998: 205-211). Similarly, the Greek state has long made limited use of EU funds for immigration and asylum management, at least some of which could have been used to ease pressures on immigration detention centres (Cheliotis 2013; see also The Guardian, 22 December 2016). Cost-free alternatives to address non-compliant issue areas, such as tackling excessive prison overcrowding by legislating to facilitate the reduced use of pretrial detention orders and custodial sentences or the enhanced use of parole, have meanwhile been inadequately deployed; a point to which we shall return later.

Accounts of non-compliance privileging institutional limitations have pointed to the country's relatively weak legal infrastructure and inefficient

\footnotetext{
${ }^{5} \mathrm{~A}$ law that passed more recently, in late 2016, entrusted the Greek Ombudsman with the power to investigate cases of alleged abuse by staff in sites of incarceration around the country, with the proclaimed aspiration, at least in part, to promote adherence to the ECHR and ensure implementation of judgments passed on such cases by the ECtHR (see, e.g., Avgi, 17 November 2016). It is too early at the time of writing to ascertain whether, and the degree to which, the new law itself will be applied in practice, let alone to evaluate its effectiveness. Greece's past record in terms of investing in, or otherwise facilitating, inspection of carceral sites by domestic bodies does not allow much scope for optimism (see, e.g., Cheliotis, 2012: 6-7).
} 
government (as measured, for instance, by the quality of policy-making and policy implementation, the quality of public service provision, and the perceived degree of impartiality and political independence of state bureaucracy) (Anagnostou and Mungiu-Pippidi 2014). Scholarship has specifically drawn attention to the weakness of inter-ministerial and inter-institutional coordination of domestic structures tasked with ensuring the implementation of ECHR requirements and ECtHR rulings, as well as the political weakness of those bodies and a broader paucity of pertinent expertise (ibid.; see also Kaboglu and Koutnatzis 2008). It is also clear, however, that opposition by a conservative judiciary has repeatedly posed an 'institutional constraint' with which Greek government initiatives to address non-compliant issue areas relating to imprisonment have had to contend, as governments themselves have complained (see further Koulouris 2009: 283).

Attempts by governments to relieve prison overcrowding through legislation meant to either restrict 'front-door' entries into the prison system or promote 'back-door' releases from it, for example, have usually been undermined by judicial practice. Not only have judges continued ordering pretrial detention at excessive rates and expanded their imposition of long-term custodial sentences to the point that any gains from decarcerative reforms to other judicial procedures have been outweighed or otherwise undercut. Judges have also persisted in making limited use of options for early release, at times even in active contravention with pertinent legal reforms and at least on one occasion (in the mid-1990s) despite the threat of disciplinary proceedings by the Supreme Court (see further Massouri 2006; Cheliotis 2010, 2011).

This is not to imply that judicial resistance has invariably been effective in thwarting legislative reforms designed to alleviate prison overcrowding. Most notably, in March 2015, the then proposed prison reform bill, whose subsequent passage quickly brought about a drastic reduction in the prison population, was staunchly opposed by the Administrative Council of the Greek Union of Prosecutors. The latter complained that proposals contained within the bill to facilitate the early release of prisoners were 'foreign to penal doctrine' since their enactment would effectively annul judicial decisions and undermine the fair and proportionate punishment of crimes (Christou-Prentziou 2015).

However partial, short-lived or otherwise inadequate, the successes achieved through decarcerative legislation carry two important implications for our analysis. First, pertinent scholarship has so far given undue weight to the weaknesses of official administration as an explanatory factor for Greece's noncompliance with the ECHR. Second, and relatedly, insofar as governments have demonstrated an ability to overcome capacity obstacles, continuing failures of the Greek state to comply with its ECHR obligations cannot but also be a matter of political will (or lack thereof); a point corroborated by the array of selfdefeating features found in various legislative attempts at decarceration, ranging, for example, from imposing overly restrictive definitions of parole eligibility, to introducing unrealistic conditions for the conversion of custodial sentences into monetary penalties, to leaving the discretionary powers of judges essentially untouched (see, e.g., Cheliotis, 2010; 2011).

Domestic politico-economic explanations 
The failure of political will to ensure Greek compliance with the ECHR and pertinent ECtHR rulings requires explanation in turn.

As argued in detail elsewhere (Cheliotis 2013, 2017), at least until the beginning of 2015, when a coalition government led by the left-wing Syriza party assumed power, the sustenance of carceral conditions that stand in blatant violation of the ECHR has served dominant politico-economic interests inside Greece. On one hand, in line with what has come to be known in pertinent Anglophone literature as the 'less eligibility' principle, whereby the working and unemployed poor are kept in check by being constantly threatened with a fate even worse than their poverty (De Giorgi 2010), the looming prospect of inhumane and degrading treatment behind bars has functioned to enhance the exploitability of the most marginalised segments of the population in the job market, whether as wage labourers or as reserves. Whilst migrants have grown to be by far the main targets of intimidation under the pretext of political, media and public discourses that routinely securitise them, so much so that they have come to outnumber Greeks in the country's crumbling prisons over recent years, the primary beneficiaries of this process have been numerous small- and medium-size enterprises profiting through labour exploitation, as well as, by extension, political elites seeking to retain and expand their electoral clienteles through sustaining the conditions for such exploitation to occur.

On the other hand, governing parties have sought to deploy incarceration as a convenient means of managing the electoral challenges of disaffection that their increasingly regressive socio-economic policies and their continuing impunity towards grand political corruption have generated amongst the broader public; disaffection that has become all the more pervasive and acute since the financial crisis hit Greece in 2009 and harsh austerity measures ensued to meet the requirements of successive bailouts. In particular, the widely publicised intensification in the use of both conventional imprisonment and immigration detention has helped to deflect and appease a range of anxieties and frustrations amongst lower- and middle-class segments of the population, from heightened concerns relating to personal and family finances, to increased anger with political elites, to a spreading sense of national humiliation before foreign audiences (Cheliotis and Xenakis 2010, 2011; Xenakis and Cheliotis 2013). In this case, the notoriously harsh conditions of penal and administrative detention have not just facilitated the symbolic resolution of anger diverted against outgroups scapegoated as dangerous. In accordance with what may be termed the 'more eligibility' principle, they have also become a rare source of empowerment for average Greek citizens, helping subconsciously to alleviate their pains of downward mobility and falling living standards by providing them with reassurance that they continue to enjoy material advantages at least over those on the margins of society-and over some foreign population at that, given the racialisation of custodial prisons and the proliferation of immigration detention sites around the country (see further Cheliotis 2013, 2017).

From a domestic politico-economic perspective, then, bringing carceral conditions in line with the ECHR must have been taken to be of insufficient utility at best, whilst risking serious counterproductive effects at worst. Indeed, repeated criticisms and sanctions for non-compliant conditions of incarceration have arguably been perversely useful to the status quo insofar as they have subtly worked as powerful reminders that bolster feelings of intimidation and 
labour exploitability amongst those occupying the bottom of the class structure, at the same time as helping to reaffirm a sense of relative superiority amongst the mainstream public. Given the exceptionally high levels of nationalism, racism and punitiveness against foreign lawbreakers amongst Greeks (including amongst the judiciary), the fact that migrants have come to be the primary targets of state punitiveness in the country appears closely interrelated with the fact that successive governments have failed to comply with ECHR provisions regarding conditions of imprisonment and immigrant detention (see further Cheliotis and Xenakis 2011; Cheliotis 2013, 2017).

\section{International drivers of Greek non-compliance}

In addition to domestic politico-economic rationales, there have also been certain international pressures that have functioned to impede Greek compliance with the ECHR. The existence and role of international drivers of national non-compliance is exemplified in the crisis that has unfurled over recent years concerning conditions of immigration detention in Greece.

As a starting point, Greece's European counterparts have played a key role in making contravention of ECHR provisions on conditions of detention practically more likely. First, EU migration and border security policies bear considerable responsibility for the magnitude of irregular flows of migrants that have become concentrated in Greece given, on one hand, the European Community's longstanding efforts to tighten regular migration routes into the region (Crawley et al. 2016), and on the other hand, the area's so-called Dublin regime, which has meant that, since 1997 , immigrants apply for regularisation in their first country of entry to the EU.

EU migration management has continued to channel irregular migrants to Greece despite awareness of the poor and worsening conditions of immigrant detention in the country, and without taking adequate steps to remedy them. Notwithstanding the obligation placed on EU member-states since 2011 not to return asylum seekers to Greece due to abysmal conditions of migrant detention there (European Commission 2016a), in the face of multiplying reports by European and international monitoring bodies, as well as by NGOs, testifying to these conditions, and the repeated validation of such accounts by ECtHR rulings (see, e.g., Mahammad and Others v. Greece, 2015), Greece's obligation to process new arrivals under the Dublin regime has persisted. In winter 2016, moreover, the European Commission announced that asylum seeker returns to Greece would be re-instigated as of March the following year, at the same time that the EU was coming under critical media scrutiny for its alleged gross mismanagement of funds intended to improve conditions in migrant detention sites in the country (The Guardian, 22 December 2016).

The EU has also contributed to poor conditions of detention in Greece by repeatedly threatening to expel the country from the Schengen area unless it immediately instigate more rigorous border control measures. In response to such threats, for example, Greece accelerated construction of prison-like asylum centres in 2012 (Greek Reporter, 13 April 2012) and established 'hot-spot' detention camps in 2016. Both initiatives were effectively predicated on practices of mass mandatory detention, in contravention of both regional and international human rights law (see, e.g., Boček 2016; Human Rights First 2012; Amnesty International 2016a). 
More generally, the EU has put pressure on Greece to manage irregular migration in ways that have lowered the standards for the treatment of migrants on Greek soil, effectively undercutting pressure from the CPT, the ECtHR and other official and non-official bodies internationally and domestically for the improved treatment of detained migrants within the country. For instance, in direct response to the EU-Turkey Statement of March 2016, which agreed the large-scale return to Turkey of irregular migrants deemed ineligible for asylum in the EU (European Commission 2016b), and under pressure of threatened expulsion from Schengen, Greece introduced legislation in April 2016 to enable 'fast-track' deportations of irregular migrants to Turkey. This process has reportedly led to forced expulsions and bulk treatment of asylum claims without proper consideration of individual cases, thereby violating ECHR obligations (see, e.g., Amnesty International 2016b). Even so, Greece has since been publicly chided for causing delays to the planned return of migrants to Turkey by continuing to consider asylum applications on an individual basis, despite this being a requirement under international human rights law (Financial Times, 28 September 2016; The Telegraph, 18 October 2016).

European counterparts are also reported to have informally exerted pressure on Greece to engage in illegal refoulements (or 'push-backs') of migrants' vessels at sea, a practice notorious for its wilful use of violence and reckless endangering of the lives of migrants (Migreurop 2009). As relayed by the Greek Minister of Migration himself in December 2015: "They don't dare to ask us to 'drown them', but if you do push-back on a plastic boat in the middle of the sea with 50 or 70 refugees aboard, you're asking me to drown them" $(B B C$ News, 27 January 2016). In sum, through the detail of their blunt and insistent official and off-the-record demands for greater border security and tighter migration controls, European political elites have exerted more effective pressure on Greece to contravene the ECHR than other CoE bodies such as the CPT and ECtHR have done in attempting to rectify Greek non-compliance.

Beyond European counter-compliance pressure on Greece, regional and international trends in compliance with human rights rules and norms have also played a tacit role in Greece's evaluation of the imperative of compliance. Whilst there is a long history of human rights non-compliance by Western states, political commitment to human rights rules and norms is today on the wane internationally, just as it was once on the ascent. As has been vividly illustrated by research into the international spread of 'clean' torture techniques that leave no physical trace, the strength of the international human rights regime and its array of monitoring bodies has correlated more with the way in which Western states and their allies have chosen to execute their abusive practices, rather than with their level of compliance per se (Rejali 2007). Over recent years, much has been written about the rise in overt violations of human rights conventions by Western states, relating both to counter-terrorism law and practices and the treatment of immigrants (see further, e.g., Douzinas 2007). This upsurge in unconcealed violations has gone hand-in-hand with efforts to critique and curtail the reach of international human rights law; amongst EU member-states, for example, the ECtHR has been subject to mounting criticism for its alleged activism in its interpretation of the ECHR and for over-reaching the scope of its authority in an effort to extend its influence and reputation (Flogaitis et al. 2013). As Oomen (2015) writes, "After decades of relatively undisputed 
expansion of the jurisdiction, caseload and normative reach of the [ECtHR], the past years have been marked by an explicit questioning - by politicians, lawyers and opinion-makers alike - of its legitimacy."

This discourse has not merely been mirrored in Greece, it has also been used to question the validity of ECtHR rulings against Greece and the efforts of domestic lobbies who would cite such rulings in their campaigns for human rights reform in the country. Thus, for instance, in 2012, when challenged by a Greek interviewer to account for ECtHR rulings against Greece, the then Greek Minister of Public Order Nikos Dendias responded as follows:

\begin{abstract}
"The first thing we should examine is how the Court judges and what decisions it reaches. The [European] Court of Human Rights has not only convicted Greece, it has convicted countless countries countless times. It has an expansionary tendency in the application of treaties, in a totally broadened manner, while the legal adequacy of its decisions [...] opens up huge questions. [...] The expansionary way of interpreting treaties, by people who are in many cases not legal professionals, and whose legal training in the philosophy of law is relatively limited, generates major issues, major issues in Greek Law, European Law, and Roman Law alike[.]"' (UNFOLLOW 2012)
\end{abstract}

The extent to which states seek to demonstrate compliance with human rights rules and norms, then, is shaped by pressures beyond the nation-state itself; pressures that may be as much nurturing of non-compliance as they may be of compliance (see further Chandler 2004; Hopwood 2007). Greek patterns of non-compliance therefore need to be understood within a context in which there has been substantial and increasing permissiveness towards and even encouragement of the forms of abuse in which Greece has been engaged, providing the country with supportive cues for continuing abusive practices.

\title{
Conclusion
}

This article shows that calculations by Greek governments of costs and benefits relating to both the domestic and international arenas, in conjunction with select institutional capacity constraints, account for Greece's long-standing noncompliance with the ECHR.

Our findings suggest that privileging national institutional capacity as the primary determinant of compliance is wanting in two important ways. On one hand, through a long historical approach to Greece's non-compliance with the ECHR in the field of incarceration, our study illustrates that problems of institutional capacity do not invariably account for continuing human rights violations. Under the 1967-74 dictatorship, for example, the grand scale of violations was, if anything, illustrative of the strong institutional capacity of the state (and this both in terms of administration and finances), rather than the reverse. Nor, as we have shown, was the junta insufficiently familiar with the expectations of the international human rights regime. On the other hand, taking a close look at the range of institutional obstacles to human rights reforms regarding conditions in prisons and immigration detention centres in contemporary Greece, we propose that consideration of institutional capacity extend to the stance and practices of key institutional actors themselves, such as the judiciary, whilst at the same time acknowledging the role of government in shaping institutional capacity in its various manifestations. 
The Greek case affirms the thesis that governments engage in cost-benefit analysis when considering compliance with international human rights rules and norms, yet our findings also stress that the costs and benefits under consideration may pertain as much to the international as to the domestic arena. Clearly, significant social and material pro-compliance pressures with which Greece has had to contend at certain critical junctures have emanated from both inside the country (e.g., rioting by prisoners) and beyond (e.g., criticism and sanctions from the CPT and the ECtHR, respectively), occasionally triggering, whether singly or together, government initiatives to tackle ongoing human rights violations in sites of incarceration. The array of powerful forces that have combined to produce an overall trend towards non-compliance with the ECHR, however, have similarly spanned influences from both the domestic and international spheres. During the 1967-74 dictatorship, the widespread use of incarceration under notoriously brutal conditions was largely targeted against the Greek Left, partly to intimidate and suppress domestic political opposition to the military regime, and partly to crush those deemed enemies of the state. But persecution of leftist constituencies also reflected the politico-economic Cold War priorities of the country's anti-communist allies in the West, whose support to the junta effectively counterbalanced the costs of non-compliance with the ECHR.

Over more recent decades, Greece's persistent failure to redress abysmal conditions of incarceration has served important politico-economic functions inside the country, from cowing disadvantaged groups into accepting exploitation in the workplace, thereby benefiting business sectors of great electoral importance to political elites, to helping successive governments limit the electoral damage wrought by their increasingly regressive socio-economic policies. At the same time, mounting criticism within Europe against the ECtHR has combined with the concurrent rise of blatant violations of international human rights conventions by various Western states to furnish Greece with ample symbolic cues towards non-compliance with the ECHR in the field of incarceration and beyond. In recent years, the EU has also set the tone for the harsh treatment specifically of migrants in carceral sites across Greece by threatening to sanction the country so as to force it into adopting stricter policies and practices of immigration control that contravene both ECHR obligations and broader international human rights legislation. With regard to immigration detention conditions as such, the international realm has even practically operated as a driver of Greek non-compliance with the ECHR, insofar as the EU has effectively fuelled overcrowding and associated problems, not least by continuing to channel large flows of irregular migration to Greece.

In sum, contrary to concerns that have been raised in scholarship on the effectiveness of international human rights regimes about the validity of causal attribution per se, our account coheres with, and provides further validation to, approaches to causation which argue not only that the identification of causal factors is a legitimate endeavour, but also that different causal factors may be inextricably bound together in a relationship of mutual constitution and cumulative efficacy (see, e.g., Kurki 2008). What this implies is that efforts to explain national propensity towards compliance with an international human rights regime need to extend beyond considering single sets of variables (e.g., domestic capacity limitations), just as they need to extend beyond considering 
single variables within given sets (e.g., pro-compliance international pressures). In so doing, moreover, one needs always to remain open to the possibility that different variables within a particular set may be exerting opposing and even counter-productive effects, as our account of both pro- and counter-compliance influences stemming from the international sphere reveals.

\section{References}

Amnesty International (2016a) 'Greece: Refugees detained in dire conditions amid rush to implement EU-Turkey deal', 7 April. Available online at: https://www.amnesty.org/en/latest/news/2016/04/greece-refugeesdetained-in-dire-conditions-amid-rush-to-implement-eu-turkey-deal/ (accessed 8 November 2016)

Amnesty International (2016b) 'Greece: Reported illegal returns of Syrian refugees to Turkey "dangerous"', Media Advisory, 21 October. Available online at: $\quad$ http://www.amnesty.eu/en/news/press-releases/eu/asylum-andmigration/greece-reported-illegal-returns-of-syrian-refugees-to-turkeydangerous-1001/\#.WCOV7RbWTzK (accessed 8 November 2016).

Anagnostou, D. (2013) 'Politics, courts and society in the national implementation and practice of ECtHR case law', in D. Anagnostou (ed.) The European Court of Human Rights: Implementing Strasbourg's Judgments on Domestic Policy, pp. 211-231. Edinburgh: Edinburgh University Press.

Anagnostou, D. and A. Mungiu-Pippidi (2014) 'Domestic implementation of human rights judgments in Europe: Legal infrastructure and government effectiveness matter', European Journal of International Law 25(1): 205-227.

Avgi (17 November 2016) 'The Ombudsman's scope of intervention widens' [in Greek] Available online at: http://www.avgi.gr/article/10813/7653545/dieurynetai-to-pedioparembases-gia-ton-synegoro-tou-polite (accessed 26 December 2016).

BBC News (27 January 2016) 'Belgium said "push migrants back to sea" - Greek Minister'. Available online at: http://www.bbc.co.uk/news/world-europe$\underline{35420967}$ (accessed 1 November 2016).

Boček, T. (2016) 'Report of the fact-finding mission by Ambassador Tomáš Boček Special Representative of the Secretary General on migration and refugees to Greece and "the former Yugoslav Republic of Macedonia" 7-11 March 2016'. Report to the Committee of Ministers, Council of Europe, 26 April 2016. Available online at: https://search.coe.int/cm/Pages/result details.aspx?ObjectId=09000016806 48495\# ftnref6 (accessed 8 November 2016).

Cardenas, S. (2007) Conflict and Compliance: State Responses to International Human Rights Pressures. Philadelphia, PA: University of Pennsylvania Press. 
Chandler, D. (2004) Constructing Global Civil Society: Morality and Power in International Relations. Basingstoke: Palgrave Macmillan.

Chatzitheodorou, G. S. (2016) 'Contemporary conditions of detention in prisons: Between European idealism and Greek Realism'[in Greek], in Crime in Crisis [in Greek]. Athens, Ant. N. Sakkoulas.

Cheliotis, L. K. (2017) 'Punitive Inclusion: The Political Economy of Irregular Migration in the Margins of Europe', European Journal of Criminology.

Cheliotis, L. K. (2013) 'Behind the Veil of Philoxenia: The Politics of Immigration Detention in Greece', European Journal of Criminology 10(6): 725-745.

Cheliotis, L. K. (2012) 'Suffering at the Hands of the State: Conditions of Imprisonment and Prisoner Health in Contemporary Greece', European Journal of Criminology 9(1): 3-22.

Cheliotis, L. K. (2011) 'Prisons and Parole', in L. K. Cheliotis and S. Xenakis (eds) Crime and Punishment in Contemporary Greece: International Comparative Perspectives, pp. 557-591. Oxford: Peter Lang AG.

Cheliotis, L. K. (2010) 'Greece', in N. Padfield, D. van Zyl Smit and F. Dünkel (eds) Release from Prison: European Policy and Practice, pp. 213-236. Cullompton: Willan Publishing.

Cheliotis, L. K. and S. Xenakis (2016) 'Punishment and Political Systems: State Punitiveness in Post-Dictatorial Greece', Punishment \& Society 18(3): 268300.

Cheliotis, L. K. and S. Xenakis (2011) 'Crime, Fear of Crime and Punitiveness', in L. K. Cheliotis and S. Xenakis (eds) Crime and Punishment in Contemporary Greece: International Comparative Perspectives, pp. 1-43. Oxford: Peter Lang AG.

Cheliotis, L. K. and S. Xenakis (2010) 'What's Neoliberalism Got to Do With It? Towards a Political Economy of Punishment in Greece', Criminology \& Criminal Justice 10(4): 353-373.

Christou-Prentziou, C. (2015) 'The 2015 Prison Reform Bill in Greece', International Relations Quarterly 6(1): 1-5.

Cole, W. (2016) 'Managing to mitigate abuse: Bureaucracy, democracy, and human rights, 1984-2010', International Journal of Comparative Sociology 57(1): 69-97.

Cole, W. (2015) 'Mind the gap: State capacity and the implementation of human rights treaties', International Organization 69(2): 405-441. 
Crawley, H., F. Düvell, K. Jones, S. McMahon and N. Sigona (2016) Destination Europe? Understanding the dynamics and drivers of Mediterranean migration in 2015. Final Report, Unravelling the Mediterranean Migration Crisis (MEDMIG). Available online at: http://www.medmig.info/wpcontent/uploads/2016/11/research-brief-destination-europe.pdf (accessed 8 November 2016).

David-Barrett, E. and K. Okamura (2016) 'Norm Diffusion and Reputation: The Rise of the Extractive Industries Transparency Initiative,' Governance 29(2): 227-246.

Dertilis, G. (2016) Seven Wars, Four Civil Wars, Seven Bankruptcies, 1821-2016 [in Greek]. Athens: Polis.

Dimopoulos, C. (1998) The Crisis of the Prison Institution and Non-Custodial Sanctions. Athens-Komotini: Ant. N. Sakkoulas Publishers [in Greek].

Douzinas, C. (2007) Human Rights and Empire: The Political Philosophy of Cosmopolitanism. Abingdon: Routledge-Cavendish.

Efimerida ton Syntakton (18 September 2016) 'For more human conditions of detention' [in Greek]. Available online at: http://www.efsyn.gr/arthro/giapio-anthropines-synthikes-kratisis (accessed 11 November 2016).

Eleftherotypia (9 July 2010) 'Supreme Court circular regarding the implementation of pre-trial detention' [in Greek].

European Commission (2016a) 'Commission adopts second Recommendation identifying steps to restore Dublin transfers to Greece'. Press release, 15 June. Available online at: http://europa.eu/rapid/press-release IP-16-2182 en.htm (accessed 8 November 2016).

European Commission (2016b) 'Communication from the Commission to the European Parliament, the European Council and the Council'. First report on the progress made in the implementation of the EU-Turkey Statement. Available online at: http://ec.europa.eu/dgs/home-affairs/what-wedo/policies/european-agenda-migration/proposal-implementationpackage/docs/20160420/report implementation euturkey agreement nr 01 en.pdf (accessed 8 November 2016).

Evans, M. D. and R. Morgan (1998) Preventing Torture: A Study of the European Convention for the Prevention of Torture and Inhuman or Degrading Torture or Punishment. Oxford: Oxford University Press.

Financial Times (28 September 2016) 'Merkel chides Greece for slow handling of asylum claims'. Available online at: https://www.ft.com/content/7426f07c8576-11e6-a29c-6e7d9515ad15 (accessed 8 November 2016). 
Flogaitis, S., T. Zwart and J. Fraser (eds) (2013) The European Court of Human Rights and Its Discontents. Cheltenham: Edward Elgar.

Franklin, J. (2008) 'Shame on you: The impact of human rights criticism on political repression in Latin America', International Studies Quarterly 52(1): 187-211.

French, D. (2015) Fighting EOKA: The British Counter-Insurgency Campaign on Cyprus, 1955-1959. Oxford: Oxford University Press.

French, D. (2011) The British Way in Counter-Insurgency, 1945-1967. New York: Oxford University Press.

Friman, H. R. (2015) 'Conclusion: Exploring the politics of leverage', in H.R. Friman (ed.) The Politics of Leverage in International Relations: Name, Shame and Sanction, pp. 201-218. Basingstoke: Palgrave Macmillan.

Gallant, T. W. (2016) Modern Greece: From the War of Independence to the Present. 2nd Edn. London: Bloomsbury.

Government of Greece (10 January 2012) Response of the Government of Greece to the Report of the European Committee for the Prevention of Torture and Inhuman or Degrading Treatment or Punishment (CPT) on its Visit to Greece from 20 to 27 January 2011. Strasbourg: Council of Europe.

Greek Reporter (13 April 2012) 'EU gives Greece two weeks to form border control plan'. Available online at: http://greece.greekreporter.com/2016/04/13/eu-gives-greece-two-weeksto-form-border-control-plan/ (accessed 1 November 2016).

Guardian, The (22 December 2016) 'Thousands of refugees left in cold, as UN and EU accused of mismanagement'. Available online at: https://www.theguardian.com/world/2016/dec/22/thousands-of-refugeesleft-in-cold-as-un-and-eu-accused-of-mismanagement (accessed 26 December 2016).

Hafner-Burton, E. M. (2008) 'Sticks and stones: Naming and shaming the human rights enforcement problem', International Organization 62(4): 689-716.

Hendrix, C. and H. Wong (2013) 'When is the pen truly mighty? Regime type and the efficacy of naming and shaming in curbing human rights abuses', British Journal of Political Science 43(3): 651-672.

Herzfeld, M. (1992) The Social Production of Indifference: Exploring the Symbolic Roots of Western Bureaucracy. Chicago, IL: The University of Chicago Press.

Hillebrecht, C. (2014a) Domestic Politics and International Human Rights Tribunals. Cambridge: Cambridge University Press. 
Hillebrecht, C. (2014b) 'The power of human rights tribunals: Compliance with the European Court of Human Rights and domestic policy change', European Journal of International Relations 20(4): 1100-1123.

Hopgood, S. (2007) The Endtimes of Human Rights. Ithaca: Cornell University Press.

Human Rights First (2012) 'Immigration Detention and the Human Rights of Migrants and Asylum Seekers: Key Challenges.' Submission to UN Special Rapporteur on the Human Rights of Migrants. Available online at: http://www.humanrightsfirst.org/wp-content/uploads/pdf/SubmissionImmigration Detention-

to Special Rapporteur on the Human Rights of Migrants.pdf (accessed 8 November 2016).

Human Rights Watch (19 May 2016) Greece: Refugee "Hotspots" Unsafe, Unsanitary. Available online at: https://www.hrw.org/news/2016/05/19/greece-refugee-hotspots-unsafeunsanitary (accessed 11 November 2016).

Karamouzi, E. (2014) Greece, the EEC and the Cold War, 1974-1979: The Second Enlargement. Basingstoke: Palgrave Macmillan.

Knaus, G. (2015a) 'Dorian Grey in Europe: The End of Shame and Human Rights', Newsletter 6/2015, European Stability Initiative. Available online at: http://www.esiweb.org/index.php?lang=en\&id=67\&newsletter ID=93 (Accessed on 8 November 2016).

Knaus, G. (2015b) 'Europe and Azerbaijan: The end of shame', Journal of Democracy 26(3): 5-18.

Koulouris, N. K. (2009) Supervision and Penal Justice: Alternative Sanctions and the Dispersion of the Prison [in Greek]. Athens: Nomiki Vivliothiki.

Krasner, S. (1999) Sovereignty: Organized Hypocrisy. Princeton, NJ: Princeton University Press.

Krasner, S. (1982) 'Structural Causes and Regime Consequences: Regimes as Intervening Variables', International Organization 36(2): 185-205.

Kurki, M. (2008) Causation in International Relations: Reclaiming Causal Analysis. Cambridge: Cambridge University Press.

Lebovic, J. and E. Voeten (2009) 'The cost of shame: International organizations and foreign aid in the punishing of human rights violators', Journal of Peace Research 46(1): 79-97. 
Massouri, G. S. (2006) The Introduction and Development of Conditional Release for Adults in Greece as Idiosyncratic Pardon [in Greek]. Athens-Komotini: Ant. A. Sakkoulas Publications.

Migreurop (2016) Europe's Murderous Borders. Available online at: http://www.migreurop.org/IMG/pdf/Rapport-Migreurop-nov2009-enfinal.pdf (accessed 8 November 2016).

Nadelmann, E. (1990) 'Global prohibition regimes: The evolution of norms in international society', International Organization 44(4): 479-526.

Nafpliotis, A. (2014) “"A Gift from God": Anglo-Greek Relations during the Dictatorship of the Greek Colonels', The Historical Review/La Revue Historique XI: 67-104.

Nye, J. (1990) 'The changing nature of world power', Political Science Quarterly 105(2): 177-192.

Oomen, B. (2015) 'A serious case of Strasbourg-bashing? An evaluation of the debates on the legitimacy of the European Court of Human Rights in the Netherlands', International Journal of Human Rights 20(3): 407-425.

Papandreou, N. (1998) The Council of Europe Fights for Democracy in Greece, 1967-69. Athens: Andreas Papandreou Foundation.

Pedaliu, E. (2011) 'A discordant note': NATO and the Greek junta, 1967-74', Diplomacy and Statecraft 22(1): 101-120.

Rejali, D. (2007) Torture and Democracy. Princeton, NJ: Princeton University Press.

Risse, T. and Ropp, S. C. (2013) 'Introduction and overview', in T. Risse, S.C. Ropp and K. Sikkink (eds) The Persistent Power of Human Rights: From Commitment to Compliance, pp. 3-25. Cambridge: Cambridge University Press.

Risse, T. and K. Sikkink (1999) 'The socialization of international human rights norms into domestic practices', in T. Risse, S. Ropp and K. Sikkink (eds) The Power of Human Rights: International Norms and Domestic Change, pp. 1-38. Cambridge: Cambridge University Press.

Smith, K.E. (2015) 'The EU as a diplomatic actors in the field of human rights', in J. Koops and G. Macaj (eds) The European Union as a Diplomatic Actor, pp. 155177. Basingstoke: Palgrave Macmillan.

Ta Nea (18 February 2016) 'At 10.287 Euros the annual cost for each prisoner in Greece, according to research' [in Greek].

The Telegraph (18 October 2016) 'EU to call on Greece to speed up migrant returns to Turkey'. Available online at: 
http://www.telegraph.co.uk/news/2016/10/18/eu-to-call-on-greece-tospeed-up-migrant-returns-toturkey/ (assessed 8 November 2016).

To Pontiki (9 October 2016) "'You come in alive, you leave dead"' [in Greek]. Available online at: http://www.topontiki.gr/article/188388/mpaineiszontanos-vgaineis-nekros (accessed 11 November 2016).

UNFOLLOW (2012) Interview with Minister of Public Order Nikos Dendias by A. Zenakos and L. Charalampopoulos, Issue 12, December. Available online at: https://www.youtube.com/watch?v=IWe9lDm7wDM (accessed 8 November 2016).

Woodhouse, C. M. (1985) The Rise and Fall of the Greek Colonels. London: Granada.

Xenakis, S. and L. K. Cheliotis (2013) 'Crime and Economic Downturn: The Complexity of Crime and Crime Politics in Greece since 2009', British Journal of Criminology 53(5): 719-745.

Xydis, S. G. (1974) 'Coups and Countercoups in Greece, 1967-1973', Political Science Quarterly 89(3): 507-538. 